\title{
Representasi Himpunan Barisan Kodon ke dalam Struktur Modul
}

\author{
Yurio Windiatmoko, Ema Carnia, Isah Aisah \\ Jurusan Matematika, Fakultas MIPA, Universitas Padjadjaran \\ Jl. Raya Bandung Sumedang KM 21 Jatinangor Sumedang 45363 \\ Email: yuriowindiatmoko@rocketmail.com,ema_carnia@yahoo.com,isah_aish@yahoo.co.id
}

\begin{abstract}
ABSTRAK
Informasi genetik memogram semua aktivitas sel di dalam tubuh diatur dalam molekul DNA. Molekul tersebut dipandang sebagai himpunan barisan kode genetik atau kodon. Kodon merupakan suatu kode aturan penamaan asam amino berdasarkan triplet nukleotida $\{A, C, G, U / T\}$ yang terdapat pada untai DNA. Himpunan barisan kodon dapat disajikan ke dalam bentuk struktur yang merupakan bagian dari pemodelan matematika aljabar abstrak. Dalam makalah ini dijelaskan bagaimana langkah-langkah mendapatkan hasil representasi tersebut secara bertahap. Tahapan diawalli dengan representasi himpunan basis nukleotida menjadi struktur grup, kemudian dilanjutkan dengan representasi himpunan kodon menjadi struktur ring dan diakhiri dengan representasi barisan kodon menjadi struktur modul.
\end{abstract}

.Kata kunci: Struktur Grup, Struktur Ring, Struktur Modul, Kodon, Nukleotida.

\begin{abstract}
The genetics information that programs all cell activity in the body is regulated in a DNA molecule. The molecule is assumed as a set of genetic code sequence or codon. Codon is a nomenclature of the amino acid based on the triplet of nucleotides $\{A, C, G, U / T\}$ located in the DNA strand. As a matter of fact, the set of codon sequence could be presented in the form of the structure that is part of the modeling of algebra mathematical abstract. This paper describes how to get the representation results step by step. The first step begins with the representation of the set of nucleotide bases into the group structure, then followed by a representation of the set of codons into ring structures, and the last step shall be representation of codon sequence into module structure.

Keywords: Group Structure, Ring Structure, Module Structure, Codon, Nucleotide.
\end{abstract}

\section{Pendahuluan}

Informasi genetik yang memprogram semua aktivitas sel terdapat dalam bentuk kode di dalam molekul DNA (deoxyribonucleic acid). DNA merupakan bahan penyusun gen yang terletak pada inti sel (nukleus). Gen merupakan suatu unit penurunan sifat yang meneruskan informasi dari induk pada keturunannya. Terdapat kurang lebih 200.000 gen di dalam DNA sel manusia. Kumpulan gen membentuk genom yaitu keseluruhan penurunan sifat atau materi genetik yang dimiliki sel suatu organisme (Campbell et al., 2005 : 325). Pada molekul DNA, nukleotida dibentuk dari tiga komponen yaitu basa nitrogen, gula pentosa dan gugus fosfat. Basanya berupa adenin (A), timin (T), guanin (G) dan sitosin (C). Untai DNA merupakan urutan basa di sepanjang gen yang akan menspesifikasi sekuen asam amino suatu protein tertentu, asam amino yang terdiri atas urutan tiga nukleotida ini disebut kodon.

Barisan kodon pada DNA ternyata dapat dipelajari secara kuantitatif melalui pemodelan matematika dengan menganggap barisan kodon tersebut sebagai sebuah kelompok himpunan yang diklasifikasikan berdasarkan operasi tertentu, dan teorema tertentu yang dipelajari pada mata kuliah Struktur Aljabar atau biasa disebut dengan aljabar abstrak. Tujuan dari paper ini yaitu untuk membuktikan himpunan barisan kodon pada DNA menjadi struktur modul. 


\section{Metode Penelitian}

Pada penelitian ini objek yang diteliti adalah Himpunan Barisan Kodon pada DNA. Diagram alur tahapan representasi struktur modul himpunan barisan kodon adalah sebagai berikut ;

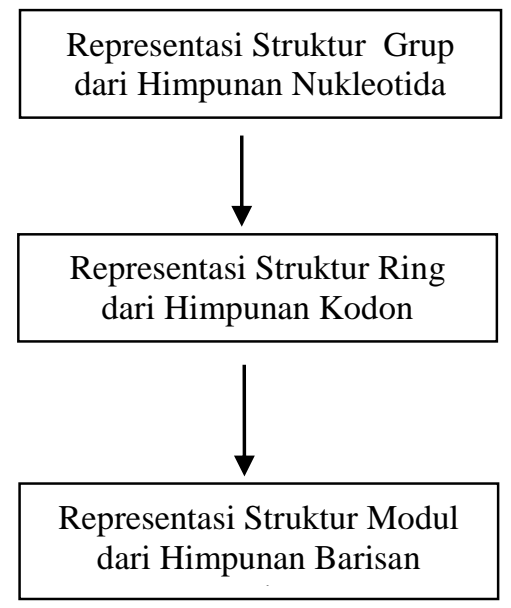

Gambar 1. Diagram Alur Tahapan Representasi Struktur Modul Himpunan Barisan Kodon.

\section{Hasil dan Pembahasan}

Sebelum membahas lebih jauh penelitian ini diberikan teori tentang struktur Modul.

Misal $R$ adalah ring dengan elemen satuan (tidak harus komutatif). Himpunan $M$ dikatakan modul kiri atas $R$ [4] dinotasikan $M ; R$-modul kiri jika memenuhi syarat-syarat sebagai berikut:

1. $(M,+)$ merupakan grup komutatif

2. Operasi perkalian skalar $\cdot: R \times M \rightarrow M$

$(\forall \alpha \in R)(\forall m \in M) \alpha \cdot m \in M$ memenuhi aksioma-aksioma sebagai berikut:

(a). $(\alpha+\beta) m=\alpha m+\beta m, \quad \forall \alpha, \beta \in R, m \in M$,

(b). $(\alpha \beta) m=\alpha(\beta m), \quad \forall \alpha, \beta \in R, m \in M$ dan

(c). $\alpha(m+n)=\alpha m+\alpha n, \quad \forall \alpha \in R, m, n \in M$.

(d). $1 m=m, \quad \forall m \in M$.

(Jika $R$ merupakan ring komutatif maka $M$ dapat dinyatakan juga sebagai $R$-modul kanan dengan mendefinisikan $m \alpha=\alpha m \quad, \forall \alpha \in R, m \in M$ )

\subsection{Grup basis-4 (Four-base group)}

Basis elemen himpunan terurut $\{\mathrm{A}, \mathrm{C}, \mathrm{G}, \mathrm{U}\}$ didapat dari pengaturan perbedaan hubungan jumlah ikatan hidrogen dan sifat kimia (purin dan pirimidin) antar nukleotida[5]. Kelompok nukleotida yang memiliki jumlah ikatan hidrogen sebanyak 3 ikatan yaitu G dan C, sedangkan kelompok nukleotida yang memiliki jumlah ikatan hidrogen sebanyak 2 ikatan yaitu A dan T/U. Untuk pengelompokan sifat kimia nukleotida, kelompok purin yaitu G dan A, sedangkan untuk kelompok nukleotida pirimidin yaitu $\mathrm{C}$ dan $\mathrm{T} / \mathrm{U}$.

Grup basis 4 dinotasikan $N_{c}$ merupakan grup yang isomorfik dengan $Z_{4}$ (bilangan bulat modulo 4) dinotasikan $N_{c} \cong Z_{4}$. 
Tabel 1. Penjumlahan himpunan $N_{c}$ dan $Z_{4}$

\begin{tabular}{|c|c|c|c|c|}
\hline+ & $A$ & $C$ & $G$ & $U$ \\
\hline$A$ & $A$ & $C$ & $G$ & $U$ \\
\hline$C$ & $C$ & $G$ & $U$ & $A$ \\
\hline$G$ & $G$ & $U$ & $A$ & $C$ \\
\hline$U$ & $U$ & $A$ & $C$ & $G$ \\
\hline
\end{tabular}

\begin{tabular}{|c|c|c|c|c|}
\hline+ & $\overline{0}$ & $\overline{1}$ & $\overline{2}$ & $\overline{3}$ \\
\hline$\overline{0}$ & $\overline{0}$ & $\overline{1}$ & $\overline{2}$ & $\overline{3}$ \\
\hline$\overline{1}$ & $\overline{1}$ & $\overline{2}$ & $\overline{3}$ & $\overline{0}$ \\
\hline$\overline{2}$ & $\overline{2}$ & $\overline{3}$ & $\overline{0}$ & $\overline{1}$ \\
\hline$\overline{3}$ & $\overline{3}$ & $\overline{0}$ & $\overline{1}$ & $\overline{2}$ \\
\hline
\end{tabular}

\subsection{Struktur Ring $C_{g}$ ( Himpunan Kodon )}

Selanjutnya himpunan $N_{c}$ yang merupakan himpunan nukleotida dikonversikan menjadi himpunan triplet nukleotida atau yang disebut dengan himpunan kodon $C_{g}$ [5] seperti terlihat pada Tabel 2.

Selanjutnya, Operasi penjumlahan pada himpunan $C_{g}$ didefinisikan sebagai berikut: Jika $x y z, x^{\prime} y^{\prime} z^{\prime} \in C_{g}$ dengan $x$ dan $x^{\prime}$ adalah basis pertama pada kodon (basis disini merujuk pada sub bab 3.1 yaitu basis nukleotida), $y$ dan $y^{\prime}$ adalah basis kedua pada kodon dan $z$ dan $z^{\prime}$ adalah basis ketiga pada kodon. Maka algoritma penjumlahan $x y z+x^{\prime} y^{\prime} z^{\prime}$ menghasilkan $x^{\prime \prime} y^{\prime \prime} z^{\prime \prime} \in C_{g}$ dinyatakan sebagai berikut :

(i) Pertama, $z+z^{\prime}$ menghasilkan basis ketiga sebut $z^{\prime \prime}$ dengan mengikuti operasi penjumlahan pada tabel $N_{c}$.

(ii) Jika basis yang dihasilkan urutannya lebih dulu dari basa-basa yang dijumlahkan, maka $z^{\prime \prime}$ yang dihasilkan dan basis $\mathrm{C}$ ditambahkan ke langkah penjumlahan selanjutnya.

(iii) Lalu, $x+x^{\prime}$ menghasilkan basis pertama kodon sebut $x^{\prime \prime}$ dengan operasi penjumlahan mengikuti operasi penjumlahan pada tabel $N_{c}$. (Aturan (ii) tetap berlaku)

(iv) Terakhir, $y+y^{\prime}$ menghasilkan basis kedua kodon sebut $y^{\prime \prime}$ dengan operasi penjumlahan mengikuti operasi penjumlahan pada tabel $N_{c}$. Sehingga hasilnya kodon $x^{\prime \prime} y^{\prime \prime} z^{\prime \prime}$.

Tabel 2. Himpunan Kodon $C_{g}$

\begin{tabular}{|c|c|c|c|c|c|c|c|c|c|c|c|}
\hline & & $\mathbf{A}$ & & C & & & $\mathbf{G}$ & & & $\mathbf{U}$ & \\
\hline & No & & & To & & & & & & & \\
\hline & 0 & AAA & & $6 \mathrm{ACA}$ & & & AGA & $R$ & 48 & \begin{tabular}{ll|l} 
AUA & I \\
\end{tabular} & \\
\hline & 1 & $\mathrm{AAC}$ & & $7 \mathrm{ACC}$ & $\mathrm{T}$ & 3 & $\mathrm{AGC}$ & $\mathrm{S}$ & 49 & \begin{tabular}{l|l} 
UC & I
\end{tabular} & \\
\hline & 2 & $\mathrm{AAG}$ & & $8 \mathrm{ACG}$ & & 34 & $\mathrm{AGG}$ & $\mathrm{R}$ & 50 & $\mathrm{UG} \mathrm{M}$ & \\
\hline & 3 & $\mathrm{AAU}$ & & $9 \mathrm{ACU}$ & & 5 & AGU & $\mathrm{S}$ & 51 & AUU I & \\
\hline & 4 & $\mathrm{CAA}$ & & \begin{tabular}{l|l|}
0 & $\mathrm{CCA}$ \\
\end{tabular} & $\mathrm{P}$ & 36 & CGA & $\mathrm{R}$ & 52 & CUA L & \\
\hline & 5 & $\mathrm{CAC}$ & & $1 \mid \mathrm{CCC}$ & & 37 & CGC & $R$ & & 3 CUC L & \\
\hline & 6 & $\mathrm{CAG}$ & & $2 \mathrm{CCG}$ & & 38 & CGG & $\mathrm{R}$ & & CUG L & \\
\hline & 7 & $\mathrm{CAU}$ & & $3 \mathrm{CCU}$ & & 39 & $\mathrm{CGU}$ & $\mathrm{R}$ & & CUU L & \\
\hline & 8 & GAA & & $4 \mathrm{GCA}$. & & 40 & GGA & G & & GUA V & \\
\hline & & GAC & & $5 \mid \mathrm{GCC}$. & & 41 & GGC & G & & GUC V & \\
\hline & & GAG & & $6 \mathrm{GCG}$. & & 42 & GGG & $\mathrm{G}$ & & GUG V & \\
\hline & 11 & $\mathrm{GAU}$ & & $7 \mathrm{GCU}$. & & 43 & GGU & $\mathrm{G}$ & & GUU V & \\
\hline & 12 & UAA & & $8 \mathrm{UCA}$ & & 44 & UGA & & & UUA L & \\
\hline & & $\mathrm{UAC}$ & & $9 \mid \mathrm{UCC}$ & & 45 & UGC & $\mathrm{C}$ & 61 & \begin{tabular}{l|l|l} 
UUC & F
\end{tabular} & \\
\hline U & & $\mathrm{UAG}$ & & $0 \mathrm{UCG}$ & & 46 & $\mathrm{UGG}$ & W & & UUG L & \\
\hline & & I & & $1|\mathrm{UCU}|$ & & & TGT & & & UUU $F$ & \\
\hline
\end{tabular}


Contoh 1. : $C G C+G U U$, dengan $x y z=C G C, x^{\prime} y^{\prime} z^{\prime}=G U U$

(i) $\quad z^{\prime \prime}=C+U=A$, karena A yang dihasilkan mendahului basis $\mathrm{C} \& \mathrm{U}$ pada urutan $\{\mathrm{A}, \mathrm{C}, \mathrm{G}, \mathrm{U}\}$ maka $\mathrm{C}$ ditambahkan ke langkah penjumlahan selanjutnya.

(ii) $\quad x^{\prime \prime}=(C+G)+C=U+C=A$, karena A yang dihasilkan mendahului basis $\mathrm{U} \& \mathrm{C}$ pada urutan $\{\mathrm{A}, \mathrm{C}, \mathrm{G}, \mathrm{U}\}$ maka $\mathrm{C}$ ditambahkan ke langkah penjumlahan selanjutnya.

(iii) $y^{\prime \prime}=(G+U)+C=C+C=G$, sehingga $x^{\prime \prime} y^{\prime \prime} z^{\prime \prime}=A G A$ atau $C G C+G U U=A G A$.

Operasi perkalian pada himpunan kodon $C_{g}$ yang dinyatakan dengan $\otimes$ didefinisikan dengan $\left(x_{1} y_{1} z_{1} \otimes x_{1} y_{1} z_{1}\right)=x_{1} y_{1} z_{1}, \quad x_{1} y_{1} z_{1}=A A C$ (untuk suatu pembangun) $\forall u, v \in C_{g}: u \otimes v=\bar{k}\left(x_{1} y_{1} z_{1}\right) \otimes \overline{k^{\prime}}\left(x_{1} y_{1} z_{1}\right)=\bar{k} \cdot \overline{k^{\prime}}\left(x_{1} y_{1} z_{1}\right)$

("." adalah operasi perkalian di $Z_{64}$ ) sehingga dapat dikatakan operasi perkalian " $\bigotimes$ ” merupakan operasi biner

Karena setiap grup siklik hingga dengan order himpunan yang sama akan isomorfik, dan dengan melalui pengaitan yang merujuk pada tabel $C_{g}$ antara kolom (i) dengan kolom "No" yang merupakan pengaitan bijektif (1-1, pada), maka Himpunan $\boldsymbol{C}_{\boldsymbol{g}}$ Isomorfik dengan $\boldsymbol{Z}_{\mathbf{6 4}}$

\subsection{Struktur Modul pada Himpunan Barisan Kodon}

Selanjutnya himpunan kodon $C_{g}$ akan diperluas menjadi himpunan barisan kodon $\mathrm{P}$ atau $\left(C_{g}\right)^{N}$ yang didefinisikan dengan grup jumlah langsung dari $C_{g}$ [5] yaitu :

$$
(P,+)=\left(\left(C_{g}\right)^{N},+\right)=\left(C_{g},+\right) \oplus\left(C_{g},+\right) \oplus \ldots . \oplus\left(C_{g},+\right) \text { (sebanyak } N \text { faktor), } \forall N \in \mathbb{Z}^{+}
$$

Unsur-unsurnya merupakan pasangan terurut dari elemen-elemen himpunan $C_{g}$, dinotasikan : $\left(\left(C_{g}\right)^{N},+\right)=\left\{\left(u_{1}, u_{2}, \ldots \ldots, u_{N}\right) \mid \forall u_{i} \in C_{g}\right\} \quad(i=1,2, \ldots, N)$, sehingga kardinalitas dari himpunan $P$ adalah $64^{N}=64 \times 64 \times \ldots \times 64$

Operasi pada $\bigoplus_{i=1}^{n} C_{g}$ didefinisikan sebagai berikut :

$$
\left(u_{1}, u_{2}, u_{3}, \ldots, u_{n}\right)+\left(v_{1}, v_{2}, v_{3}, \ldots, v_{n}\right)=\left(u_{1}+v_{1}, u_{2}+v_{2}, u_{3}+v_{3}, \ldots, u_{n}+v_{n}\right)
$$

Untuk $\forall u_{i}, v_{i} \in C_{g}$ dan $\forall u_{i}+v_{i} \in C_{g}$, maka himpunan $\bigoplus_{i=1}^{n} C_{g}$ dibawah operasi penjumlahan merupakan grup, dinotasikan $\left(\oplus_{i=1}^{n} C_{g},+\right)$, dan disebut grup jumlah langsung dari $C_{g}$.

Dengan demikian dapat diperlihatkan bahwa :

1. $\left(C_{g},+\right)$ adalah grup komutatif (Sudah terbukti).

2. $\left(Z_{64},+, \otimes\right)$ adalah ring dengan elemen satuan (Sudah terbukti pada pembuktian $Z_{n}$ merupakan ring komutatif dengan elemen satuan).

3. Operasi perkalian skalar $: Z_{64} \times C_{g} \rightarrow C_{g}$

$\left(\forall \bar{k}, \bar{l} \in Z_{64}\right)\left(\forall x_{1} y_{1} z_{1}\left(\right.\right.$ generator $\left.\left.C_{g}\right), x y z, x^{\prime} y^{\prime} z^{\prime} \in C_{g}\right)$

$\bar{l}(x y z)=\bar{l} \cdot \bar{k}\left(x_{1} y_{1} z_{1}\right)=x^{\prime} y^{\prime} z^{\prime} \in C_{g}$,

Akan ditunjukkan operasi $\cdot$ bersifat well defined.

Ambil sebarang $\left(\overline{l_{2}}, x_{2} y_{2} z_{2}\right),\left(\overline{l_{3}}, x_{3} y_{3} z_{3}\right) \in Z_{64} \times C_{g}$ dengan $\left(\overline{l_{2}}, x_{2} y_{2} z_{2}\right)=\left(\overline{l_{3}}, x_{3} y_{3} z_{3}\right)$, harus ditunjukkan $\cdot\left(\overline{l_{2}}, x_{2} y_{2} z_{2}\right)=\cdot\left(\overline{l_{3}}, x_{3} y_{3} z_{3}\right)$$$
\cdot\left(\overline{l_{2}}, x_{2} y_{2} z_{2}\right)=\overline{l_{2}}\left(x_{2} y_{2} z_{2}\right)=\overline{l_{3}}\left(x_{3} y_{3} z_{3}\right)=\cdot\left(\overline{l_{3}}, x_{3} y_{3} z_{3}\right) \text {, }
$$

Dengan terlihat bahwa operasi ( $)$ well defined. Selanjutnya akan ditunjukkan operasi ( $)$ memenuhi aksioma-aksioma sebagai berikut: 
(a). $(\bar{l}+\bar{p}) x y z=(\bar{l}+\bar{p}) \bar{k}\left(x_{1} y_{1} z_{1}\right)=\bar{l} \cdot \bar{k}\left(x_{1} y_{1} z_{1}\right)+\bar{p} \cdot \bar{k}\left(x_{1} y_{1} z_{1}\right)$ $=\bar{l}(x y z)+\bar{p}(x y z)$,

$\forall \bar{l}, \bar{p}, \bar{k} \in Z_{64}, x_{1} y_{1} z_{1}\left(\right.$ generator $\left.C_{g}\right), x y z \in C_{g}$.

(b). $(\bar{l} \cdot \bar{p}) x y z=(\bar{l} \cdot \bar{p}) \cdot \bar{k}\left(x_{1} y_{1} z_{1}\right)=\bar{l} \cdot\left(\bar{p} \cdot \bar{k}\left(x_{1} y_{1} z_{1}\right)\right)=\bar{l}(\bar{p}(x y z))$,

$\forall \bar{l}, \bar{p}, \bar{k} \in Z_{64}, x_{1} y_{1} z_{1}\left(\right.$ generator $\left.C_{g}\right), x y z \in C_{g}$.

(c). $\bar{l}\left(x y z+x^{\prime} y^{\prime} z^{\prime}\right)=\bar{l}\left(\bar{k}\left(x_{1} y_{1} z_{1}\right)+\overline{k^{\prime}}\left(x_{1} y_{1} z_{1}\right)\right)=\bar{l} \cdot \bar{k}\left(x_{1} y_{1} z_{1}\right)+\bar{l} \cdot \overline{k^{\prime}}\left(x_{1} y_{1} z_{1}\right)=\bar{l}(x y z)+$ $\bar{l}\left(x^{\prime} y^{\prime} z^{\prime}\right), \forall \bar{l}, \bar{k}, \overline{k^{\prime}} \in Z_{64}, x_{1} y_{1} z_{1}$ (generator $C_{g}$ ) $x y z, x^{\prime} y^{\prime} z^{\prime} \in C_{g}$.

(d). $\overline{1}(x y z)=\overline{1} \cdot \bar{k}\left(x_{1} y_{1} z_{1}\right) \quad=\bar{k}\left(x_{1} y_{1} z_{1}\right)=x y z$,

$\forall x_{1} y_{1} z_{1}\left(\right.$ generator $\left.C_{g}\right), x y z \in C_{g}$.

Sehingga, dari pernyataan 1, 2 dan 3 dapat disimpulkan bahwa $C_{g}$ modul atas $Z_{64}$.

\section{Simpulan}

Dari penjelasan yang diuraikan di atas dapat disimpulkan bahwa himpunan Barisan Kodon memiliki struktur Aljabar sebagai Modul.

\section{Daftar Pustaka}

1. Campbell, N.A. dan Reece, J.B. 2005. Campbell Biology (9th ed.). Illinois : Pearson Education.

2. Durbin, J.R. 2009. Modern Algebra an Introduction (6th ed.). New York : John Wiley \& Sons

3. Dummit, D.S. dan Foote, R.M. 2004. Abstract Algebra (3rd ed.). New York : John Wiley \& Sons.

4. Fraleigh, J.B. 2003. A First Course in Abstract Algebra (7th ed.).

5. Sanchez, R., Morgado, E. dan Grau, R 2005 Gene Algebra from a Genetic Code Algebraic Structure J. Math Biol. 51 : 431-457

6. Ngili, Y. 2010. Biokimia Dasar. Bandung : Rekayasa Sains. 
Windiatmoko et al / JMI Volume 10 No 1, April 2014, hal 49-54 